\title{
MENINGKATKAN KETERAMPILAN BERPIKIR RASIONAL SISWA MELALUI MODEL SAINS TEKNOLOGI MASYARAKAT PADA KONSEP SUMBER DAYA ALAM
}

\author{
Sopyan Hendrayana \\ Universitas Pasundan \\ sopyanhendrayana@unpas.ac.id
}

\begin{abstract}
This research is motivated by the low of understanding of students about the concept of SDA (Sumber Daya Alam/Natural resources) in the fourth grade of SDN Cikalang and is not used to perform realistic solutions in daily life. In other words, learning has not been able to improve rational thinking skills. Sekaitan with these problems then the problem in this study as follows. 1) Students' learning activities during SDA learning using STM model, 2) Student's scientific attitude during learning SDA concept using STM model, 3) Rational thinking skill of students in natural resource learning using STM model. Solving the problem by applying the STM model in improving students' rational thinking skills, supported by learning activities and scientific attitudes. This research was conducted using Elliot model and supported by observation method, discussion and demonstration. Based on data obtained from the average results of the process of learning activities of students in detail are: cycle I of 2.89, cycle II of 3.09, and cycle III of 3.31. Students' scientific attitudes in detail are: cycle I of 2.86, cycle II of 3.05, and third cycle of 3.28. While the result of rational learning skill rational learning skill by using STM model in every cycle that is: cycle I equal to 66.94, cycle II equal to 72.90, and cycle III equal to 79.85. Thus, it can be concluded that in science learning in elementary school using the STM model can improve students' rational thinking skills supported by the development of learning activities and scientific attitude.
\end{abstract}

Keywords : Scientific Process Skills (KPS); Rational Thinking; and Community Technology Science (STM).

\section{ABSTRAK}

Penelitian ini dilatarbelakangi permasalahan masih rendahnya pemahaman siswa tentang konsep SDA di kelas IV SDN Cikalang dan tidak terbiasanya melakukan tindakan pemecahan yang realistis dalam kehidupan sehari-hari. Dengan kata lain, pembelajaran yang dilakukan belum mampu meningkatkan keterampilan berpikir rasional. Sekaitan dengan permasalahan tersebut maka yang menjadi rumusan masalah dalam penelitian ini sebagai berikut. 1) Aktivitas belajar siswa pada saat pembelajaran SDA dengan menggunakan model STM, 2) Sikap ilmiah siswa selama pembelajaran konsep SDA dengan menggunakan model STM, 3) Keterampilan berpikir rasional siswa dalam pembelajaran SDA dengan menggunakan model STM. Pemecahan masalahnya dengan menerapkan model STM dalam meningkatkan keterampilan berpikir rasional siswa, dengan didukung aktivitas belajar dan sikap ilmiah. Penelitian ini dilakukan dengan menggunakan model Elliot dan didukung metode pengamatan, diskusi serta demonstrasi. Berdasarkan data yang diperoleh dari hasil rata-rata nilai proses aktivitas belajar 
siswa secara rinci yaitu: siklus I secara rinci yaitu: siklus I sebesar 2.86, siklus II sebesar 3.05, dan siklus III sebesar 3.28. Sedangkan hasil evaluasi keterampilan berpikir rasional pembelajaran IPA dengan menggunakan model STM pada setiap siklus yaitu: siklus I sebesar 66.94, siklus II sebesar 72.90, dan siklus III sebesar 79.85. Dengan demikian, dapat disimpulkan bahwa dalam pembelajaran IPA di SD dengan menggunakan model STM dapat meningkatkan keterampilan berpikir rasional siswa dengan didukung aktivitas belajar dan sikap ilmiah.

Kata kunci : Keterampilan Proses Sains (KPS); Berpikir Rasional; dan Sains Teknologi Masyarakat (STM).

\section{A. PENDAHULUAN}

Kemajuan IImu Pengetahuan dan Teknologi (IPTEK) yang semakin pesat menuntut kita untuk senantiasa meningkatkan segala kemampuan yang kita miliki. Untuk mengimbangi segala kemajuan tersebut salah satu upaya yang dapat dilakukan dalam memersiapkan diri yaitu melalui pendidikan. Lapangan pendidikan merupakan wilayah yang sangat luas. Ruang lingkupnya mencakup seluruh pengalaman dan pemikiran manusia tentang pendidikan. Setiap orang semasa kecilnya pernah mengalami pendidikan, atau setiap orang baik orang tua maupun guru, telah melaksanakan pendidikan. Namun tidak setiap orang mengerti dalam arti yang sebenarnya tentang pendidikan, dan tidak setiap orang mengalami pendidikan ataupun menjalankan pendidikan sebagaimana mestinya.

Menurut undang-undang nomor 20 tahun 2003 tentang Sistem Pendidikan Nasional.
Pendidikan adalah usaha sadar dan terencana untuk mewujudkan suasana belajar dan proses pembelajaran agar peserta didik secara aktif mengembangkan potensi dirinya untuk memiliki kekuatan spiritual keagamaan, pengendalian diri, kepribadian, kecerdasan, ahlak mulia, serta keterampilan yang diperlukan bangsa dan negara.

Sebagai bagian yang tidak terpisahkan dari sistem pendidikan nasional pembelajaran di sekolah hendaknya memiliki fungsi dan tujuan yang mengacu pada pendidikan nasional. Dalam kaitan ini sekolah hendaknya mengembangkan kemampuan dan membentuk watak serta peradaban bangsa yang bermartabat dalam rangka mencerdaskan kehidupan bangsa, dan bertujuan untuk mengembangkan potensi siswa agar menjadi manusia yang beriman dan bertakwa kepada Tuhan Yang Maha Esa, berakhlak 
mulia, sehat, berilmu, cakap, kreatif, mandiri, dan menjadi warga negara yang demokratis serta bertanggung jawab. Maka dari itu perlu adanya pengemasan pembelajaran yang dapat menggali potensi-potensi siswa agar siswa siap menghadapi tantangan yang ada.

Potensi setiap siswa tentu memiliki karakteristik yang berbedabeda, dan guru perlu mengetahui benar sifat-sifat serta karakteristik tersebut agar dapat memberikan pembinaan dengan baik dan tepat, sehingga dengan hal tersebut dapat meningkatkan potensi kecerdasan berpikir siswa yang sesuai dengan perkembangannya. Menurut Jean Piaget ( Sumantri dan Syaodih, 2007:1.15) mengemukakan proses karakteristik siswa sampai mampu untuk berpikir seperti orang dewasa melalui empat tahap perkembangan, di antaranya sebagai berikut.

1. Tahap sensori motor $(0 ; 0-2 ; 0$ tahun)

Kegiatan intelektual pada tahap ini hampir seluruhnya mencakup gejala yang diterima secara langsung melalui indera.

2. Tahap praoperasional $(2 ; 0-7 ; 0$ tahun)
Pada tahap ini perkembangan sangat pesat. Lambang-lambang bahasa yang dipergunakan untuk menunjukkan benda-benda nyata bertambah dengan pesat.

3. Tahap operasional konkrit (7;0 11;0 tahun)

Kemampuan berpikir logis muncul pada tahap ini.

4. Tahap operasional formal $(11 ; 0-$ 15;0 tahun)

Tahap ini ditandai dengan pola berpikir orang dewasa.

Melihat dari karakteristik perkembangan berpikir di atas, guru semakin tertuntut untuk dapat memberikan stimulus yang relevan terhadap tingkat perkembangan berpikir siswa. Stimulus tersebut dapat diberikan dalam pembelajaran dengan menekankan pada pengalaman siswa untuk masa yang akan datang. Maka dari itu pelajaran atau ilmu pengetahuan dapat menjadi alat untuk perkembangan berpikir siswa dengan menekankan pembelajaran pada realita yang aplikatif terhadap kehidupan, baik sekarang maupun masa akan datang.

IImu Pengetahuan Alam (IPA) sebagai salah satu ilmu pengetahuan yang berperan penting terhadap 
segala kemajuan baik yang terjadi pada perkembangan teknologi, makhluk hidup, alam maupun lingkungan, di mana pendidikan IPA diharapkan dapat menjadi wahana bagi siswa untuk mempelajari diri sendiri dan alam sekitar, serta prospek pengembangan lebih lanjut dalam menerapkan di kehidupan sehari-hari. Proses pembelajaran lebih menekankan pada pemberian pengalaman langsung untuk mengembangkan kompetensi agar menjelajahi dan memahami alam sekitar secara ilmiah. Dengan demikian fungsi pembelajaran IPA di SD antara lain adalah memberikan pengetahuan tentang lingkungan alam maupun lingkungan buatan dengan pemanfaatannya bagi kehidupan sehari-hari, mengembangkan keterampilan proses sains, mengembangkan wawasan, sikap dan nilai yang berguna untuk meningkatkan kualitas hidup. Melihat hal tersebut, maka IPA dapat begitu kuat memberikan sumbangan demi tercapainya tujuan pendidikan.

Menurut Mechling dan Oliver (Yuliariatiningsih dan Irianto, 2009:7) 'penekanan yang diberikan dalam pengajaran keterampilan proses IPA adalah

pada

keterampilanketerampilan berpikir'. Keterampilan berpikir dapat memacu perkembangan siswa dalam memahami setiap masalah yang dihadapinya serta bagaimana cara untuk memecahkannya, salah satu keterampilan berpikir tersebut yaitu keterampilan berpikir rasional. Adapun keterampilan berpikir rasional siswa Sekolah Dasar (SD) yang masih sederhana seperti menghafal, membayangkan, menglasifikasi, menggeneralisasikan, dan membandingkan.

Sehubungan dengan di atas, maka peran guru dalam upayanya menciptakan pembelajaran yang efektif dan bermakna bagi siswa sangat penting. Salah satu ciri proses pengajaran efektif adalah dengan melibatkan aktivitas siswa pada saat pembelajaran berlangsung. Siswa diberikan kebebasan untuk mengeksplorasi sendiri tentang apa yang ingin mereka ketahui melalui pengamatan (observasi) dengan menggunakan seluruh panca indera. (penglihatan, pendengaran, penciuman dan perabaan).

Dari hasil pengamatan peneliti mengenai lingkungan, banyak 
kejadian-kejadian yang tidak diharapkan di mana merugikan manusia itu sendiri seperti kecelakaan atau musibah yang memang dilatar belakangi oleh kecerobohan manusia. Hal ini terjadi karena adanya kesalahan manusia (human eror), terkadang berbuat tanpa dipikirkan terlebih dahulu. Di mana, pengetahuan dan wawasan yang sudah dimiliki dari hasil pendidikannya tidak diaplikasikan untuk memecahkan permasalahan dan memberikan solusi terhadap permasalahan yang sedang dihadapi. Berdasarkan pengalaman peneliti pada saat melakukan observasi di SD Negeri Cikalang, peneliti memeroleh keterangan bahwa siswa kelas IV mengalami kesulitan dalam memahami konsep IPA khususnya SDA, tanpa adanya tindakan pemecahan yang realistis dalam kehidupan sehari-hari. Dengan kata lain, pembelajaran yang dilakukan belum mampu meningkatkan berpikir rasional siswa.

Berdasarkan latar belakang maka peneliti mengambil judul Meningkatkan Keterampilan Berpikir Rasional Siswa Melalui Model Sains Teknologi Masyarakat Pada Konsep Sumber Daya Alam.

\section{B. LANDASAN TEORI}

1. Pembelajaran IPA di SD

Pembelajaran sebagai proses belajar dibagun oleh guru untuk mengembangkan kreativitas berpikir yang dapat meningkatkan kemampuan berpikir siswa, serta dapat meningkatkan kemampuan mengkonstruksi pengetahuan baru sebagai upaya meningkatkan penguasaan yang baik terhadap materi pelajaran. Karli dan Yuliariatiningsih (2004: 28) bahwa untuk mendorong siswa supaya aktif dan antusias dalam mengikuti pembelajaran maka "siswa didorong agar mengemukakan pengetahuan awalnya tentang konsep yang akan dibahas. Bila perlu, guru memancing dengan memberikan pertanyaanpertanyaan yang problematik tentang fenomena alam yang ditemui seharihari dengan mengkaitkan konsepkonsep yang dibahas".

Pembelajaran juga sebagai proses yang kompleks, karena kegiatan pembelajaran senantiasa menyatukan berbagai komponen pembelajaran secara terintegrasi, seperti tujuan pembelajaran yang harus dicapai, materi, metode, media, sumber pembelajaran, evaluasi, 
siswa, guru dan lingkungan pembelajaran lainnya. Pada prosesnya guru juga harus memahami dan menguasai hakekat materi pembelajaran yang diajarkannya sebagai suatu pelajaran yang dapat mengembangkan kemampuan berpikir siswa yang disesuaikan dengan model pembelajaran yang dapat merangsang kemampuan siswa untuk belajar.

Pembelajaran dibagi menjadi dua yaitu pembelajaran dalam konteks pendidikan formal dan pembelajaran dalam konteks pendidikan nonformal. Pendidikan formal yaitu pendidikan di sekolah, sebagian besar terjadi di kelas dan lingkungan sekolah, sebagian kecil pembelajaran terjadi juga di lingkungan masyarakat. Sedangkan pendidikan nonformal justru sebaliknya yaitu proses pembelajaran sebagian besar terjadi dalam lingkungan masyarakat. Pembelajaran formal merupakan istilah yang menunjukan kegiatan guru dan siswa. Istilah pembelajaran muncul dari istilah proses belajar dan pengajaran. Istilah pembelajaran mengacu pada segala kegiatan yang berpengaruh langsung terhadap proses belajar siswa dan interaksi siswa yang tidak dibatasi oleh kehadiran guru secara fisik.

Keberhasilan

suatu pembelajaran tergantung bagaimana interaksi antara guru dengan siswa. Interaksi guru dan siswa dapat berjalan dengan baik apabila guru kompeten mengelola kelas. Langkah awal yang perlu diketahui guru dalam mengelola kelas adalah mengenali siswa yang akan dihadapi. Apabila guru tidak paham tentang siswa yang akan difasilitasi, maka mustahil guru dapat memilih strategi pembelajaran yang tepat dan materi pembelajaran yang sesuai. Namun tidak hanya itu kemampuan guru juga harus didukung dengan keterampilan mengajar, di antaranya keterampilan membuka pembelajaran, keterampilan menutup pembelajaran, keterampilan menjelaskan, keterampilan bertanya, keterampilan memberikan penguatan, keterampilan membimbing diskusi, keterampilan mengajar kelompok kecil, serta keterampilan mengadakan variasi pembelajaran. Hal ini sejalan dengan pendapat Sukirman dan Kasmad (2006:172) yang menyatakan bahwa salah satu variasi yang digunakan adalah variasi stimulus "variasi stimulus adalah keragaman 
stimulus yang diberikan, sehingga memungkinkan siswa dapat merespon melalui alat indera yang dimilikinya".

Berdasarkan uraian di atas pembelajaran adalah proses interaksi belajar yang dirancang oleh guru, baik interaksi siswa dengan guru, siswa dengan siswa, maupun siswa dengan lingkungan atau media pembelajaran, sehingga akan menghasilkan perubahan yang mengacu pada tujuan pembelajaran. Hal tersebut sejalan dengan pendapat Piaget (Sagala, 2008:26) bahwa 'pengetahuan dibentuk oleh individu, sebab individu melakukan interaksi terus menerus dengan lingkungan'. Interaksi siswa dengan lingkungan akan semakin mengembangkan fungsi intelektual siswa dalam perkembangannya secara kualitatif, sehingga siswa dapat menjalankan tugas perkembangannya secara optimal sesuai dengan apa yang diharapkan.

Melalui pengamatan terhadap segala sesuatu yang berada di sekitar kita, maka kita akan menemukan bahwa bumi tempat kita hidup atau alam semesta ini ternyata penuh dengan fenomena-fenomena yang menakjubkan, penuh dengan keragaman yang memukau, yang semuanya itu menimbulkan pertanyaan tentang mengapa dan bagaimana semuanya itu dapat terjadi. IPA merupakan suatu ilmu yang menawarkan cara-cara kepada kita untuk dapat menjawab pertanyaan-pertanyaan itu, IPA juga menawarkan cara kepada kita untuk dapat memahami kejadian, fenomena, dan keragaman yang terdapat di alam semesta, serta bagaimana cara agar kita dapat hidup dengan menyesuaikan diri terhadap lingkungan.

2. Keterampilan Berpikir Rasional Keterampilan berpikir merupakan kemampuan seseorang untuk memecahkan atau mengatasi berbagai permasalahan, bagaimana proses pengeksploitasian fakta ataupun gejala menjadi hasil baru yang positif bagi dirinya maupun lingkungannya.

Keterampilan seseorang dalam berpikir memiliki perbedaan antara yang satu dengan yang lainnya, hal tersebut bergantung kepada bagaimana seseorang tersebut memahami masalah dan latar belakangnya. Keterampilan berpikir yang dikembangkan pada penelitian ini yaitu keterampilan berpikir rasional. 
Keterampilan berpikir rasonal menurut Novak (Yuliariatiningsih, 2000:6).

Keterampilan berpikir rasional merupakan bentuk kemampuan berpikir seseorang yang lebih diarahkan untuk memecahkan berbagai macam permasalahan dengan menggunakan sekumpulan proses mental dari yang sederhana menuju ke yang kompleks.

Pada dasarnya setiap siswa mempunyai potensi dalam berpikir rasional, hal itu terbukti bahwa siswa sebagai manusia memiliki kelebihan dari makhluk lainnya, yakni dengan memiliki otak yang setiap bagiannya memiliki fungsi tersendiri, di mana setiap bagiannya harus dikembangkan agar mencapai keseimbangan dengan fungsi yang optimal. Potensi berpikir rasional terdapat di belahan otak kiri. Hal itu dapat terlihat pada tabel 2.1 sebagai berikut.

Tabel 1

Fungsi Belahan Otak Kiri dan Kanan (Yusuf, Syamsu. 2008:103)

\begin{tabular}{|c|c|}
\hline Fur & $\begin{array}{c}\text { Fungsi Otak } \\
\text { Kanan }\end{array}$ \\
\hline $\begin{array}{l}\text { Berpikir rasional, } \\
\text { Ilmiah, } \\
\text { Kritis, Logis, } \\
\text { Analitis, }\end{array}$ & $\begin{array}{l}\text { Berpikir Holistik, } \\
\text { Non linier, Non } \\
\text { verbal, Intuitif, } \\
\text { Imajinatif, Non }\end{array}$ \\
\hline
\end{tabular}

\begin{tabular}{|l|l|}
\hline $\begin{array}{l}\text { Referensial, dan } \\
\text { Konvergen. }\end{array}$ & $\begin{array}{l}\text { Referensial, } \\
\text { Divergen dan } \\
\text { Mistik }\end{array}$ \\
\hline
\end{tabular}

Proses berpikir rasional memiliki 10 tingkatan yang harus dilewati oleh perkembangan siswa pada umumnya, dari yang sederhana hingga yang komplek, dari jenjang berpikir mudah sampai berpikir sulit, di antaranya sebagai berikut.

a. Menghafal (merupakan kemampuan mengingat)

b. Membayangkan (kemampuan untuk menghasilkan rumusan pengetahuan yang baru)

c. Menglasifikasi

(kemampuan menggolongkan atau mengkatagorikan dengan kriteria tertentu)

d. Menggeneralisasi (pengenalan beberapa obyek atau kejadian)

e. Membandingkan (membedakan obyek pengamatan dengan menggunakan panca indera)

f. Mengevaluasi (kemampuan untuk dapat mengambil keputusan atas dasar penilaian dari suatu obyek, baik secara kualitatif maupun secara kuantitatif)

g. Menganalisa (kemampuan untuk dapat menguraikan suatu bangun, 


$\begin{array}{lcr}\text { pengertian } & \text { dan } & \text { menunjukkan } \\ \text { adanya } & \text { keterkaitan } & \text { antara } \\ \text { komponen } & \text { satu } & \text { terhadap } \\ \text { komponen lainnya) } & \end{array}$

h. Mensintesa (kemampuan yang melibatkan keterampilan berimajinasi atau berkreasi)

i. Mendeduksi (kemampuan yang melibatkan keterampilan mensintesa dengan mengidentifikasi, menglasifikasi, dan mensintesa untuk memecahkan masalah),

j. Menginferensi (melibatkan semua keterampilan di atas untuk menafsirkan yang telah terkumpul), (Yuliariatiningsih, 2000:13)

Dari ke sepuluh tingkatan tersebut siswa harus dapat menguasainya yang disesuaikan dengan tingkat kemampuan berpikir dan tingkat perkembangan usia. Pada dasarnya siswa yang masih duduk di bangku SD-pun sudah memiliki potensi dalam tingkat keterampilan berpikir yang komplek, seperti mengevaluasi, menganalisa, ataupun menginferensi. Tentu kemampuan yang dapat ditunjukkan masih dalam kemampuan yang sederhana, tidak seperti kemampuan yang dapat ditunjukkan oleh siswa sekolah menengah.

Dari sepuluh tingkatan tersebut yang akan dijadikan fokus kajian penelitian meliputi menghafal, membayangkan, menglasifikasikan, menggeneralisasikan, dan membandingkan. Hal itu dikarenakan pada usia SD khususnya siswa kelas IV kemampuan berpikirnya masih tahap transisi dari tahap satu menuju tahap ke dua dalam teori berpikir Van Hiele, hal tersebut ditunjukkan dengan kemampuan siswa dalam menentukan sifat-sifat dari suatu obyek dengan melakukan pengamatan, pengukuran, menggambar, dan membuat model serta mengklasifikasi obyek berdasarkan sifatnya. Namun bukan berarti siswa kelas IV SD tidak memiliki potensi untuk kemampuan berpikir tahap ke tiga, maupun ke empat Van Hiele. Hal ini dimaksudkan untuk terciptanya keoptimalan kemampuan berpikir siswa untuk setiap tahapan sebelum menuju tahapan berikutnya, agar tahapan berikutnya siswa tidak mengalami hambatan yang signifikan.

3. Pembelajaran Model STM pada Konsep SDA 
Pendas : Jurnal IImiah Pendidikan Dasar, ISSN Cetak : 2477-2143 ISSN Online : 2548-6950 Volume II Nomor 1, Juni 2017

Pembelajaran model STM pada konsep SDA dimulai dengan mengangkat permasalahan atau isuisu SDA yang sedang berkembang di lingkungan masyarakat. Permasalahan atau isu yang diangkat adalah mengenai pengelolaan sumber daya alam yang mempunyai dampak terhadap kelestarian lingkungan.

Setelah

menentukan

permasalahan atau isu yang akan dibahas kegiatan selanjutnya yaitu melaksanakan pembelajaran sesuai dengan rencana yang telah dibuat. Pelaksanaan pembelajaran pada konsep SDA dengan menggunakan model STM terdiri dari empat tahapan, yaitu:

a. Tahap invitasi

Pada tahap ini guru menyajikan suatu permasalahan atau isu mengenai konsep SDA, misalnya dengan memberikan ilustrasi tentang penebangan pohon dan pemburuan hewan secara liar yang merusak kelestarian alam. Untuk merangsang minat siswa terhadap masalah tersebut dapat ditempuh dengan cara membacakan berita atau artikel di surat kabar serta menunjukan gambar-gambar tentang kerusakan lingkungan akibat penebangan dan pemburuan hewan secara liar, kemudian guru melakukan tanya jawab dengan siswa untuk mengetahui pengetahuan awal yang dimiliki siswa tentang konsep SDA.

b. Tahap eksplorasi

Pada tahap ini siswa dibagi menjadi beberapa kelompok untuk melakukan kegiatan eksplorasi. Ekplorasi tersebut dilakukan melalui pengamatan yang dipandu dengan LKS. Pengamatan dapat berlangsung di lingkungan maupun melalui media pembelajaran seperti gambar maupun benda nyata lainnya. Yuliariatiningsih dan Irianto (2008:93) bahwa "media pembelajaran digunakan untuk mengganti sebagian besar dari peran guru sebagai pemberi informasi atau pemberi materi pembelajaran".

c. Tahap penjelasan dan solusi

Pada tahap ini siswa diminta untuk melaporkan hasil pengamatannya. Setelah itu siswa bersama guru melakukan diskusi untuk mencari solusi dari permasalahan tentang SDA yang ada di lingkungan sekitar siswa. Namun dalam kegiatan diskusi kelompok apabila guru kurang dalam mengondisikan siswa maka kegiatan diskusi kelompok akan sedikit kurang 
optimal, menurut Sumantri dan Permana (1999: 150) menyatakan bahwa "kelemahan metode kelompok yaitu kerja kelompok hanya memberikan kesempatan kepada peserta yang aktif dan mampu untuk berperan sedangkan peserta didik yang terbelakang tidak berbuat apaapa".

d. Tahap pengambilan tindakan

Pada tahapan ini siswa melakukan pengambilan tindakan berupa kampanye atau ajakan untuk berbuat, laporan lisan atau tertulis baik itu berbentuk poster, keliping dan memanfaatkan barang bekas atau sampah untuk dibuat kerajinan. Misalnya siswa membuat poster yang bertema menyelamatkan dan melestarikan SDA yang ada di lingkungan sekitar. Siswa juga membuat kerajinan dari botol air mineral kemasan gelas yang kemudian dibuat menjadi hiasan jendela.

4. Penelitian yang Relevan

Penelitian yang memfokuskan terhadap keterampilan berpikir rasional memang masih terbilang sedikit, sedangkan penggunaan model STM dalam penelitian di SD sudah cukup banyak, adapun penelitian yang sebelumnya pernah dilakukan di antaranya oleh:

a. Ariefin, Santy (2010:134). Dengan judul "Model STM untuk meningkatkan kesadaran siswa terhadap lingkungan pada konsep SDA". Hasil belajar dari penelitian tersebut mengalami peningkatan. Hal ini berdasarkan nilai rata-rata individu dari setiap siklus yang bertambah, untuk siklus I mendapat nilai rata-rata 57.7, siklus ॥ 66.9, dan siklus III 78.3.

b. Kusniati, Rina (2010:170). Dengan judul "Meningkatkan keterampilan berpikir rasional siswa melalui pendekatan tematik di kelas III SD". Hasil belajar dari penelitian tersebut mengalami peningkatan. Hal ini berdasarkan nilai rata-rata individu dari setiap siklus yang bertambah, untuk siklus I mendapat nilai ratarata 56.72, siklus II 69.33, dan siklus III 72.02 .

c. Umam, Komarul (2010:97). Dengan judul "Penggunaan model Sains Teknologi Masyarakat untuk meningkatkan hasil belajar siswa pada konsep Sumber Daya Alam" yang dilakukan di kelas IV SD Negeri IX. Hasil belajar dari penelitian tersebut mengalami 
peningkatan. Hal ini Berdasarkan nilai rata-rata individu dari setiap siklus yang bertambah, untuk siklus I mendapat nilai rata-rata 69.41 , siklus II 83.78, dan siklus III 90.8.

\section{METODE PENELITIAN}

1. Metode Penelitian

Kegiatan penelitian pada dasarnya suatu kegiatan pencarian atau penyelesaian atas masalah yang ditemukan dengan

cara mengumpulkan data melalui pengukuran, menganalisis data yang telah terkumpul, mensintesis, kegiatan selanjutnya membandingkan, menghubungkan data yang telah diperoleh dan kegiatan menafsirkan. Kegiatan penelitian bisa terlaksana dengan baik dan dapat menyelesaikan masalah yang ditemukan apabila menggunakan metode penelitian yang tepat. Metode penelitian ini menentukan rancangan penelitian yang akan dilaksanakan. Dalam rancangan penelitian menggambarkan langkah-langkah penelitian yang harus ditempuh, waktu penelitian, sumber data, data apa yang akan dikumpulkan, dan bagaimana mengumpulkan serta mengolah data tersebut.
Metode penelitian yang peneliti pilih pada penelitian ini yaitu dalam bentuk Penelitian Tindakan Kelas (PTK). Menurut Arikunto (2006:3) "penelitian tindakan kelas merupakan suatu pencermatan terhadap kegiatan belajar berupa sebuah tindakan, yang sengaja dimunculkan dan terjadi dalam sebuah kelas secara bersama". Sedangkan menurut Corey (Abidin, 2009: 105). 'Action Reserch is the process by which practitioners attempt to study their problems scientifically in order to guide, correct, and evaluate their decisions and actions'. Bahwa penelitian tindakan kelas merupakan seperangkat kegiatan yang bertujuan untuk memperbaiki dan mengevaluasi keputusan dan tindakan yang dilakukan dalam pelaksanaan perbaikan tersebut. Jadi dapat diambil garis besar bahwa PTK adalah suatu bentuk penelitian yang dilakukan oleh guru ataupun peneliti dalam upayanya untuk memperbaiki dan meningkatkan hasil belajar siswa yang dilakukan dalam proses pembelajaran melalui serangkaian tindakan.

PTK tersebut termasuk ke dalam pendekatan kualitatif. Pendekatan kualitatif merupakan suatu pendekatan yang bertujuan untuk 
mendeskripsikan dan menganalisis suatu fenomena atau kejadian, aktivitas, sikap, persepsi, dan pemikiran secara individu maupun kelompok. Jadi pendekatan kualitatif sangat tepat dalam menyelesaikan masalah dan mencari solusi atas masalah yang ditemukan peneliti yaitu masalah yang terjadi dalam kelas.

Tahapan-tahapan dalam PTK menurut Arikunto (2006:16) yaitu "perencanaan, pelaksanaan, pengamatan, dan refleksi”. Ke empat tahapan ini membentuk siklus yang harus dilalui, yaitu satu putaran kegiatan beruntun yang akan kembali ke langkah semula. Jadi satu siklus mencakup penyusunan rancangan sampai dengan refleksi.

Tujuan dari PTK yaitu untuk memperbaiki proses pembelajaran. Perbaikan ini dilakukan secara terusmenerus selama kegiatan penelitian dilakukan. Oleh karena itu dalam pelaksanaannya PTK dapat dilihat pada gambar di bawah ini.

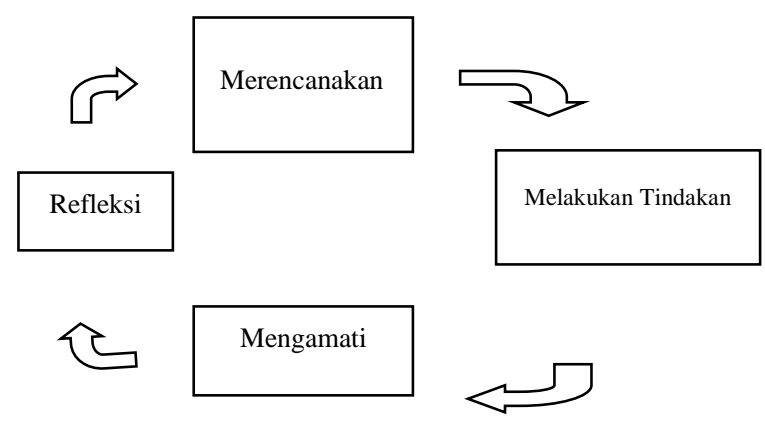

Gambar 3.1

Tahap-tahap dalam PTK (Wardhani, 2007: 2.4)

\section{Langkah}

merencanakan

merupakan langkah pertama dalam setiap kegiatan, tanpa rencana kegiatan yang kita lakukan tidak akan terarah. Rencana akan menjadi acuan dalam melaksanakan tindakan, tanpa tindakan rencana hanya merupakan angan-angan yang tidak pernah menjadi kenyataan. Selanjutnya agar tindakan dapat di ketahui keberhasilannya maka perlu dilakukan pengamatan, berdasarkan pengamatan ini dapat diketahui hasil dari tindakan yang dapat menentukan hal-hal apa saja yang perlu diperbaiki agar tindakan yang dilakukan dapat mencapai tujuan yang diinginkan khususnya untuk mencapai tujuan pembelajaran.

Tujuan tersebut tidak akan tercapai apabila tidak ada kolaborasi atau kerjasama yang baik antara guru sebagai peneliti, siswa sebagai objek yang akan diteliti dan pengamat. Upaya peneliti untuk menciptakan kolaborasi yang baik dilakukan dengan membuat perencanaan penelitian mulai dari desain lokasi atau desain penelitian, 
mengidentifikasi subjek yang akan diteliti, menentukan instrumen dan teknik pengumpulan data.

2. Desain Penelitian

Model PTK yang digunakan dalam penelitian ini yaitu mengacu pada model John Elliot. Model PTK John Elliot menggambarkan pelaksanaan yang terdiri atas tiga siklus dengan setiap siklusnya terdiri atas tiga tindakan, dari setiap tindakan akan menghasilkan tindakan berikutnya, manakala dalam tindakan sebelumnya terdapat kelemahan maka dilakukanlah refleksi dan evaluasi, sehingga melalui langkahlangkah tersebut akan lebih memudahkan peneliti dalam upaya meningkatkan keterampilan berpikir rasional melalui penguasaan pemahaman siswa dari hasil belajar yang didapatkan.

Instrumen penelitian yang dijadikan sebagai alat mengumpulkan data yaitu lembar observasi, lembar wawancara, lembar kerja siswa (LKS), catatan lapangan, lembar evaluasi.

\section{HASIL PENELITIAN DAN PEMBAHASAN}

1. Siklus I
Pada pelaksanaan siklus I tindakan pertama. Diketahui bahwa pada kegiatan awal invitasi keadaan siswa masih ribut dan menyebabkan keadaan kelas menjadi tidak terkondisi. Sedangkan pada tindakan kedua terdapat siswa yang melemparlempar kertas dan ribut. Serta tindakan ketiga terdapat siswa yang menangis karena kehilangan pinsil dan terlihat kurang bersemangat. Melihat hal tersebut guru berusaha mengondisikan siswa dengan cara membuat kesepakatan tentang seruan kelas, yakni dengan memanggil "Anak-anak" maka secara serentak siswa akan menjawab "Siap"dengan posisi duduk yang siap untuk belajar. Namun pada setiap tindakan guru berusaha membangkitkan semangat dan motivasi dengan cara melakukan ice breaking, baik uji konsentrasi maupun dalam bentuk permainan. Kemudian guru menginstruksikan siswa untuk menyiapkan alat tulis. Hal tersebut sesuai dengan menurut Thorndike (Sagala. 2008:42) yaitu 'prinsip law of rediness, belajar akan berhasil apabila individu memiliki kesiapan untuk belajar'.

Namun selain itu untuk memberikan stimulus agar skema 
pengetahuan siswa dapat empat di halaman sekolah sedangkan berkembang, guru berusaha kelompok lima melakukan memberikan suatu masalah atau isu pengamatan di dalam kelas. melalui pertanyaan-pertanyaan yang Pengamatan tersebut dilakukan berkaitan dengan kehidupan sehari- terhadap materi pengertian SDA dan hari agar dapat menarik perhatian jenis-jenis SDA berdasarkan asalnya. siswa untuk mengikuti pembelajaran. Hal ini sejalan dengan pendapat yang dikemukakan oleh Karli dan Yuliariatiningsih (2004: 28) bahwa untuk mendorong siswa supaya aktif dan antusias dalam mengikuti pembelajaran maka "siswa didorong agar mengemukakan pengetahuan awalnya tentang konsep yang akan dibahas. Bila perlu, guru memancing dengan memberikan pertanyaanpertanyaan yang problematik tentang fenomena alam yang ditemui seharihari dengan mengkaitkan konsepkonsep yang dibahas".

Pada tahap eksplorasi siswa dibentuk ke dalam lima kelompok untuk melakukan pengamatan. Pada tindakan pertama dan kedua pengamatan dilakukan terhadap lingkungan. Kelima kelompok tersebut melakukan pengamatan di tempat yang berbeda, kelompok pertama dan kelompok tiga melakukan pengamatan di kebun sekolah, kelompok kedua di aliran sungai dekat sekolah, kelompok Pada tahapan ini akan terlihat sikap ilmiah siswa baik dalam menunjukkan rasa ingin tahu maupun dalam berpikir terbuka. Sedangkan pada tindakan ketiga pengamatan dilakukan dengan menggunakan media kartu bergambar. Hal tersebut seiring dengan pendapat Piaget (Sagala, 2008:26) bahwa 'pengetahuan dibentuk oleh individu, sebab individu melakukan interaksi terus menerus dengan lingkungan'.

Pada tahap eksplorasi awalnya siswa menolak untuk belajar berkelompok secara heterogen, dan terlihat belum bisa bekerjasama dengan kelompoknya. Berdasarkan temuan lapangan, hasil observasi dan lembar wawancara. $\mathrm{Hal} \mathrm{itu}$ disebabkan siswa tidak terbiasa belajar berkelompok. Melihat hal tersebut guru berusaha memberikan penguatan motivasi ekstrinsik demi memicu munculnya motivasi intrinsik siswa, dan pada akhirnya keadaan kelas dapat kembali terkondisi. Hal 
tersebut sesuai dengan pendapat Sardiman (2010:90) "motivasi ekstrinsik adalah motif yang berfungsi karena adanya rangsangan luar".

Tahap berikutnya yaitu penjelasan konsep dan solusi. Pada tahap ini siswa diajak untuk bercurah pendapat tentang pemahamannya terhadap hasil pengamatan yang telah dilakukan. Hal ini bertujuan agar siswa dapat mengemukakan buah pikirannya dan menghasilkan solusi yang terbuka. Hal itu sejalan dengan pendapat Reason (Sanjaya, 2006:203) 'berpikir (thinking) adalah proses mental seseorang yang lebih dari sekedar mengingat (remembering) dan memahami (comprehending)'.

Pada tahap penjelasan dan solusi, saat perwakilan kelompok melaporkan hasil pengamatan, kelompok yang lain terlihat kurang memperhatikan temannya yang sedang melaporkan. Hal ini terjadi karena siswa merasa jenuh menunggu kelompok yang melaporkan hasil pengamatan dan menunggu kelompoknya maju ke depan untuk melaporkan hasil pengamatan. Adapun upaya yang dilakukan guru adalah dengan memberikan penguatan terhadap hasil kerja kelompok yang tampil sehingga kelompok yang lain tidak merasa bosan dan memerhatikan teman kelompok yang sedang tampil. Hal ini sejalan dengan pendapat Karli dan Yuliariatiningsih (2004: 31) yang menyatakan bahwa "saat siswa memberikan penjelasan-penjelasan solusi yang didasarkan pada hasil observasinya ditambah dengan penguatan guru, maka siswa dapat menyampaikan gagasan, membuat model, membuat rangkuman dan kesimpulan".

Pada tahap pengambilan tindakan, siswa merasa kesulitan untuk memecahkan masalah atau isu yang ada di lingkungan sekolah dan masyarakat. Hal ini disebabkan karena siswa belum terbiasa diberikan soal aplikasi atau penerapan (C3). Sebelumnya siswa hanya diberikan soal keterampilan berpikir rasional yaitu soal nomor satu tentang mengembangkan kemampuan membayangkan dan menggeneralisasi, soal nomor dua mengembangkan kemampuan menglasifikasi atau menggolongkan, soal nomor tiga mengembangkan kemampuan menghafal dan soal 
nomor empat mengembangkan kemampuan membandingkan atau membedakan. Oleh karena itu, guru perlu membiasakan siswa dengan memberikan soal aplikasi yang berkaitan dengan isu dalam kehidupan sehari-hari sehingga siswa terbiasa dan mampu menyelesaikan masalah.

Berdasarkan Taksonomi Bloom (Sudjana 2009: 24) menyatakan bahwa "tes tentang aplikasi dapat menentukan tindakan atau keputusan tertentu dalam menghadapi situasi baru dengan menggunakan prinsip dan generalisasi yang relevan". Pendapat tersebut juga sejalan dengan pendapat Karli dan Yuliariatiningsih (2004: 31) bahwa "aplikasi ini bertujuan agar siswa dapat membuat keputusan, menggunakan pengetahuan dan keterampilan, berbagai informasi dan gagasan, mengajukan saran baik bagi individu maupun masyarakat yang berhubungan dengan pemecahan masalah".

Adapun tes akhir atau evaluasi yang diteliti dalam penelitian ini yaitu tes keterampilan berpikir rasional. Keterampilan berpikir rasional siswa ditekankan pada kemampuan menghafal,

membayangkan, menglasifikasi, menggeneralisasi, dan membandingkan. Adapun hasil evaluasi dari keterampilan berpikir rasional siklus I.

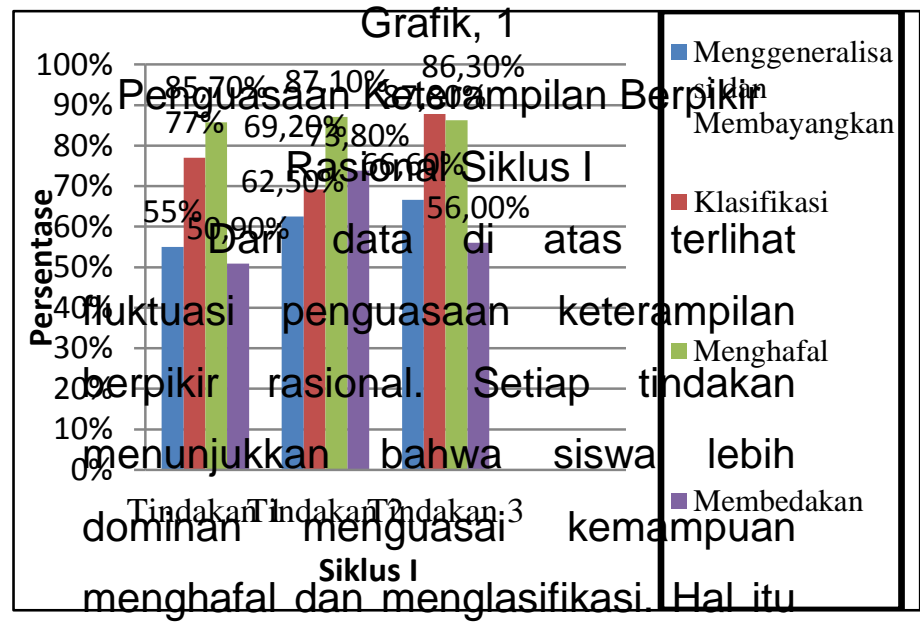

disebabkan karena siswa lebih konseptual terhadap buku sumber dan siswa belum terbiasa diberikan soal yang bersifat aplikatif. Di mana siswa sebelumnya lebih terbiasa dengan pembelajaran yang konvensional.

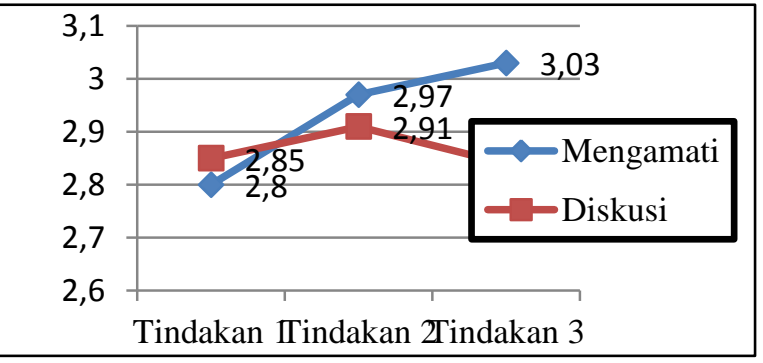


Grafik 2

Fluktuasi Aktivitas Belajar Siswa

Siklus I

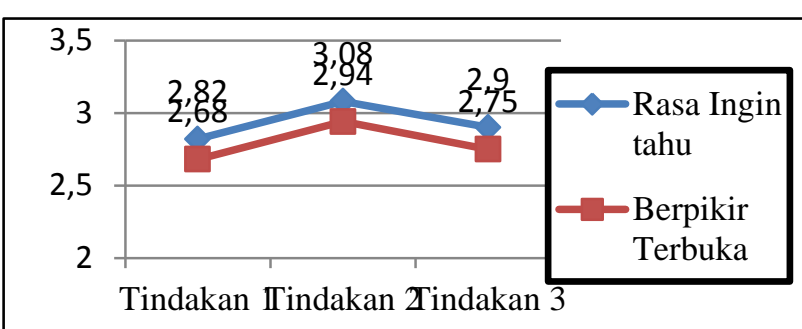

Grafik, 3

Fluktuasi Sikap IImiah Siswa Siklus I

2. Siklus II

Pada tindakan pertama, kegiatan awal ada tiga orang siswa yang masih asyik main-main dengan teman sebangkunya, hal itu tentu saja mempengaruhi teman sekelas lainnya, sehingga suasana menjadi ribut. Begitupun yang terjadi pada tindakan kedua, di mana siswa terlihat lelah karena sebelumnya telah melaksanakan pembelajaran olahraga, sedangkan pada tindakan ketiga terdapat dua orang siswa yang masih mengobrol. Melihat temuan esensial tersebut guru tentu saja tidak tinggal diam, melainkan guru langsung melakukan variasi stimulus yakni dengan melakukan ice breaking. Ice breaking ini untuk menarik perhatian siswa

agar

dapat

mengikuti

pembelajaran dengan baik. Hal ini sejalan dengan pendapat Sukirman, dan Kasmad (2006:172) yang menyatakan bahwa salah satu variasi yang digunakan adalah variasi stimulus "variasi stimulus adalah keragaman stimulus yang diberikan, sehingga memungkinkan siswa dapat merespon melalui alat indera yang dimilikinya".

Pada tahap invitasi sudah ada peningkatan. Hal ini terlihat dari tingginya respon siswa dalam menjawab pertanyaan yang diajukan guru tentang isu atau masalah yang ada di lingkungan sekolah atau masyarakat.

Pada tahap eksplorasi tindakan kedua guru menggunakan media berupa mie, snack tarro, dan waffer. Ada beberapa siswa yang memainmainkan media, dan media yang ada kurang diberdayakan dengan baik. Seharusnya media tersebut diberdayakan, agar siswa termotivasi untuk mengikuti pembelajaran dan mempermudah siswa untuk mengetahui serta memahami konsep yang dipelajari. Selain itu dengan media dapat membantu guru. Hal ini sejalan dengan pendapat 
Yuliariatiningsih dan Irianto (2008:93) bahwa "media pembelajaran digunakan untuk mengganti sebagian besar dari peran guru sebagai pemberi informasi atau pemberi materi pembelajaran".

Namun pada tindakan tiga, pada saat eksplorasi ada satu kelompok yang anggota kelompoknya berebut untuk mengerjakan LKS. Temuan tersebut sejalan dengan teori yang dikemukakan oleh Sumantri dan Permana (1999: 150) yang menyatakan bahwa "kelemahan metode kelompok yaitu kerja kelompok hanya memberikan kesempatan kepada peserta yang aktif dan mampu untuk berperan sedangkan peserta didik yang terbelakang tidak berbuat apa-apa". Untuk mencegah hal tersebut terjadi lagi, maka guru perlu memberikan pengarahan di dalam mengerjakan LKS harus secara bergantian dan siswa harus bisa bekerjasama dengan teman kelompoknya.

Tahap penjelasan konsep dan solusi menunjukan peningkatan. Ketika ada anggota kelompok siswa yang melaporkan hasil pengamatan, siswa lain memerhatikan dan mendengarkan serta aktif menjawab pertanyaan ketika guru memberikan penguatan terhadap hasil kerja kelompok. Bahkan pada tindakan kedua terdapat siswa yang berbeda pendapat tentang maksud dari gambar yang tertera pada LKS. Hal ini sejalan dengan pendapat Harley dan Davis (Sagala, 2008:43) yang menyatakan bahwa salah satu prinsip belajar 'proses belajar dapat terjadi dengan baik apabila siswa ikut terlibat secara aktif di dalamnya'.

Dalam pembelajaran siswa tidak hanya diberikan ilmu pengetahuan tetapi siswa juga diberikan keterampilan berpikir dan kreativitas untuk memecahkan suatu masalah yang sedang berkembang di lingkungan sekolah dan masyarakat. $\mathrm{Hal}$ ini sejalan dengan pendapat yang dikemukakan oleh Gagne (Karli dan Yuliariatiningsih 2004:31) bahwa "untuk terjadinya belajar pada siswa diperlukan beberapa aspek yang saling berhubungan antara satu dengan yang lain seperti: keterampilan berpikir, sikap, keterampilan motorik, menginformasikan". Hal tersebut mendukung tujuan pendidikan dasar yaitu memberikan dasar perkembangan kepribadian anak 
dalam aspek sikap, perilaku, daya cipta, dan kreativitas yang sangat diperlukan dalam menyesuaikan diri dengan lingkungannya serta perkembangan fisik dan mental anak.

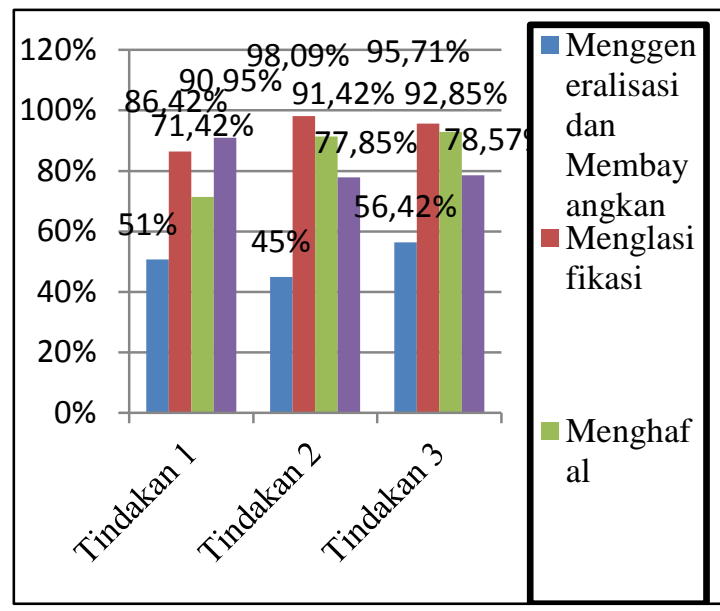

Grafik 4

Grafik Penguasaan Keterampilan

Berpikir Rasional Siklus II

Dari data di atas terlihat fluktuasi penguasaan keterampilan berpikir rasional. Setiap tindakan menunjukkan bahwa siswa lebih dominan menguasai kemampuan menghafal dan menglasifikasi. Hal itu disebabkan karena siswa lebih konseptual terhadap buku sumber dan siswa belum terbiasa diberikan soal yang bersifat aplikatif. Namun dari grafik di atas kemampuan siswa dalam membedakan sudah menunjukkan adanya perkembangan dari siklus I, walaupun pada siklus II tindakan dua mengalami penurunan.
Berdasarkan temuan lapangan, hal itu disebabkan karena pada tindakan kedua dan ketiga soal yang diberikan tentang kemampuan membedakan lebih sulit.

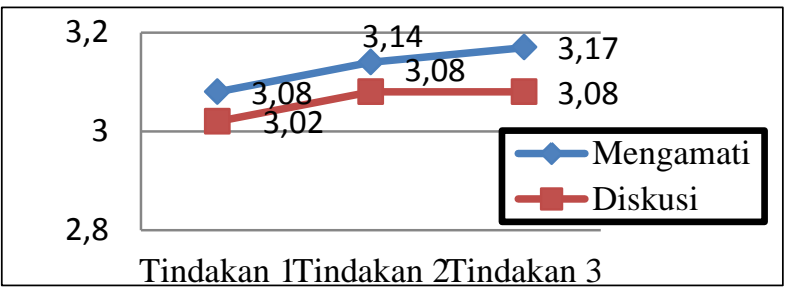

Grafik 5

Fluktuasi Aktivitas Belajar Siswa

Siklus II

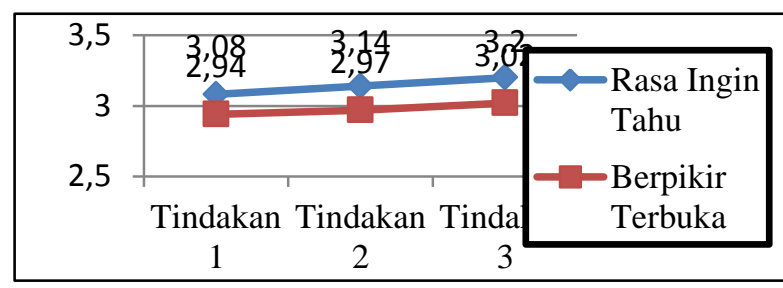

Grafik 6

Fluktuasi Sikap IImiah Siswa Siklus II 3. Siklus III

Pada tahap invitasi guru memberikan suatu isu yang ada di lingkungan sekolah dan masyarakat, bahkan pada tindakan ketiga ada salah satu siswa yang main-main, bahkan kedapatan dua orang siswa yang sedang mengobrol tentang bermain layang-layang. Melihat hal tersebut upaya yang dilakukan guru yaitu dengan memberikan pengarahan pada siswa tersebut untuk taat pada peraturan. 
Pada tahap eksplorasi siswa diberi kesempatan untuk mengamati gambar dampak positif dan negatif pengambilan SDA terhadap lingkungan dan gambar cara menjaga kelestarian lingkungan dalam LKS. Melalui kegiatan pengamatan berkelompok tersebut siwa dapat meningkatkan kerjasama, dapat menghargai pendapat teman kelompoknya dan dapat menumbuhkan pembelajaran bermakna. Melalui belajar bermakna konsep yang dibelajarkan akan bertahan lebih lama dan selalu diingat oleh siswa. Hal tersebut sejalan dengan pendapat Ausubel (Sutardi dan Sudirjo, 2007:15) 'belajar bermakna adalah suatu proses dikaitkannya informasi baru pada konsep-konsep relevan yang terdapat pada struktur kognitif seseorang'

Pada tahap penjelasan dan solusi mengalami peningkatan. Ketika ada teman kelompoknya melaporkan hasil pengamatan siswa memerhatikan, mendengarkan hasil laporan dari kelompok lain dan ada beberapa siswa yang mengajukan pertanyaan.

Pada tahap pengambilan tindakan ketika pada tindakan tiga siswa diajak untuk menerapkan keterampilan berpikir rasional dengan menglasifikasi sampah yang ada di lingkungan, yaitu sampah organik dan sampah non organik, siswa terlihat antusias ketika harus dilibatkan pada tindakan pemecahan masalah lingkungan, mulai dari masalah sederhana hingga yang komplek. Hal ini sesuai dengan pendapat Novak (Yuliariatiningsih, 2000:6).

Keterampilan berpikir rasional merupakan bentuk kemampuan berpikir seseorang yang lebih diarahkan untuk memecahkan berbagai macam permasalahan dengan menggunakan sekumpulan proses mental dari yang sederhana menuju ke yang kompleks.

Adapun tingkat fluktuasi perkembangan siswa dalam keterampilan berpikir rasional siklus III dari setiap tindakan dapat dilihat pada grafik di bawah ini.

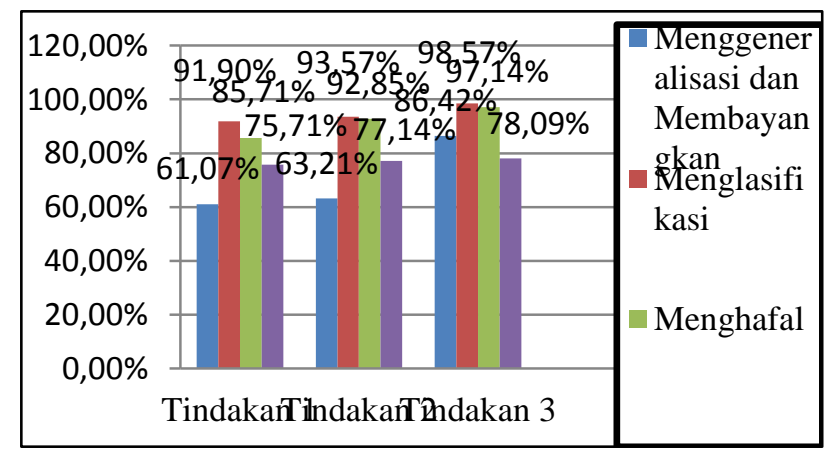

Grafik 7 
Grafik Keterampilan Berpikir Rasional

Siklus III

Dari data di atas terlihat fluktuasi penguasaan keterampilan berpikir rasional. Setiap tindakan menunjukkan bahwa siswa lebih dominan menguasai kemampuan menghafal dan menglasifikasi. Hal itu disebabkan karena siswa lebih konseptual terhadap buku sumber dan siswa belum terbiasa diberikan soal yang bersifat aplikatif. Namun selain itu perkembangan kemampuan menggeneralisasi, membayangkan dan membedakanpun secara bertahap menunjukkan adanya peningkatan ke arah lebih baik.

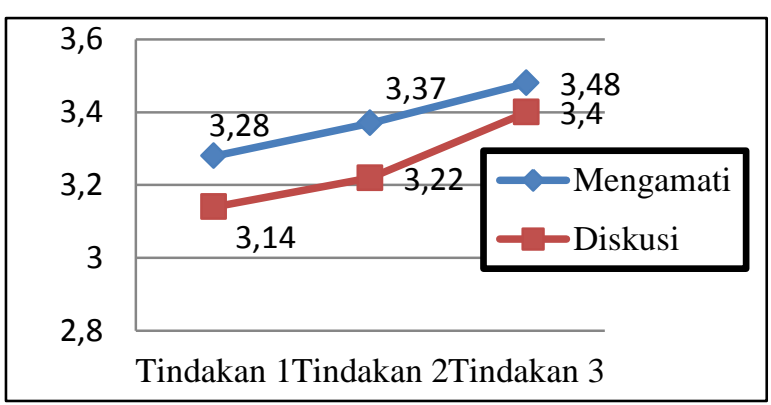

Grafik 8

Fluktuasi Aktivitas Belajar Siswa

Siklus III

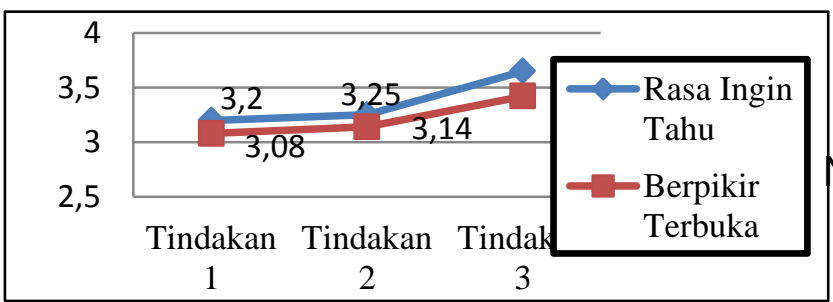

Grafik 9
Fluktuasi Sikap IImiah Siswa Siklus III Fluktuasi sikap ilmiah siswa dalam menunjukkan rasa ingin tahu dan berpikir terbuka mengalami peningkatan. Hal itu disebabkan siswa sudah mulai menunjukkan keberanian untuk dapat mengajukan pertanyaan dan menambahkan.

Pada pelaksanaan penelitian ini, dalam proses pembelajaran setiap siklusnya terlihat adanya perkembangan kemampuan siswa dalam berpikir rasional, aktivitas belajar (mengamati dan diskusi) serta sikap ilmiah (rasa ingin tahu dan berpikir terbuka). Setelah dianalisis ternyata pembelajaran lebih bermakna bagi siswa karena berkaitan langsung dengan permasalahan atau isu yang ada di sekitar sekolah maupun masyarakat yang muncul dalam kehidupan sehari-hari.

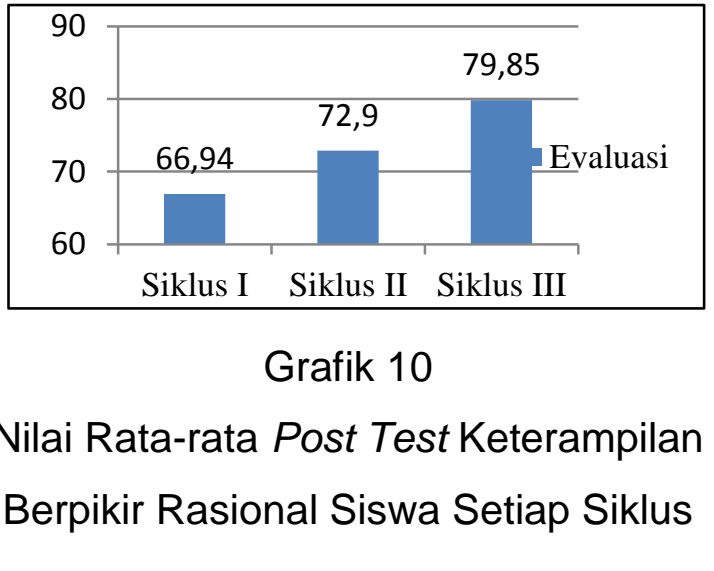




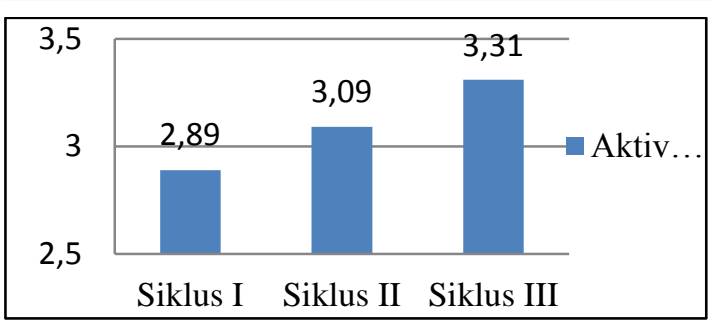

Grafik 11.

Nilai Rata-rata Aktivitas Belajar Siswa

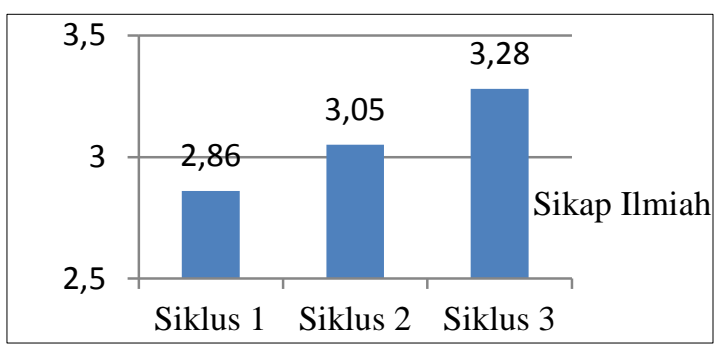

Grafik 4.12.

Nilai Rata-rata Sikap IImiah Belajar Siswa Setiap Siklus

\section{E. KESIMPULAN}

Berdasarkan hasil penelitian dan pembahasan yang telah diuraikan pada bab sebelumnya, maka penelitian ini dapat diambil kesimpulan sebagai berikut:

1. Aktivitas belajar siswa dalam pembelajaran IPA dengan penggunaan model STM di kelas IV SDN Cikalang mengalami peningkatan yang signifikan. Hal tersebut tergambarkan dari peran aktif siswa dalam menemukan konsep yang dipelajari tentang SDA. Adapun aktivitas yang dilakukan siswa dalam menemukan dan melakukan pembuktian konsep yaitu melalui pengamatan dan diskusi kelompok serta didukung dengan penggunaan metode demonstrasi. Aktivitas belajar siswa setiap siklusnya mengalami peningkatan, adapun rinciannya yaitu: siklus I sebesar 2.89 (siswa hampir mendekati cukup dalam berpartisipasi aktif), siklus II sebesar 3.09 (siswa cukup berpartisipasi aktif), dan siklus III sebesar 3.31 (siswa sudah berpartisipasi aktif dengan baik).

2. Sikap ilmiah dalam pembelajaran IPA dengan penggunaan model STM di kelas IV SDN Cikalang mengalami peningkatan yang signifikan. Hal tersebut tergambar dari sikap siswa di setiap tahapan model STM khususnya pada tahap eksplorasi, penjelasan konsep dan solusi, serta pengambilan tindakan. Adapun sikap ilmiah yang muncul pada saat menemukan dan melakukan pembuktian konsep yaitu: rasa ingin tahu siswa dan sikap berpikir terbuka. Hal tersebut terlihat pada saat siswa mengajukan pertanyaan, ataupun pada saat memberikan pendapat. Adapun rincian peningkatan sikap 
ilmiah siswa di antaranya, siklus I sebesar 2.86 (siswa hampir mendekati cukup dalam menunjukkan minat belajar), siklus II sebesar 3.05 (siswa cukup dalam menunjukkan minat belajar), dan siklus III sebesar 3.28 (siswa dapat menunjukkan minat belajar dengan baik).

3. Penggunaan model STM dalam pembelajaran konsep SDA dapat meningkatkan keterampilan berpikir rasional siswa. Hal tersebut ditunjukkan oleh tes hasil belajar siswa secara individu pada tiap siklus. Aspek keterampilan berpikir rasional yang dijadikan fokus penelitian antara lain keterampilan membayangkan, menggeneralisasi, menglasifikasi, menghafal, maupun membandingkan. Adapun nilai ratarata yang diperoleh tiap siklus yaitu : siklus I sebesar 66.94, siklus II sebesar 72.90, sedangkan pada siklus III meningkat menjadi 79.85 . Adapun indikator nilai rata-rata kelas dari hasil evaluasi yaitu $\leq 66$ (kurang) sedangkan $\geq 66$ (baik). Hal ini dilihat dari kriteria ketuntasan minimal (KKM) pelajaran IPA yang ada di SDN Cikalang yaitu 66.00.
DAFTAR PUSTAKA

Abdussakir. (2009). Teori Berpikir. [Online]. Tersedia: http://abdussakir. wordpress.com/pengalamanbelajar-sesuai-teori berpikir-vanhiele. [22 Januari 2011].

Abidin, Yunus. (2009). Guru dan Pembelajaran Bermutu. Bandung : Rizqi.

Ariefin, Santy. (2010). Model STM untuk Meningkatkan Kesadaran Siswa Terhadap Lingkungan pada Konsep SDA. Skripsi FIP UPI Bandung: Tidak diterbitkan.

Arikunto, Suharsimi. (2006). Penelitian Tindakan Kelas. Jakarta: Bumi Aksara.

Basrowi dan Suwandi. (2008). Prosedur Penelitian Tindakan Kelas. Bogor: Ghalia Indonesia.

B.S.N.P. (2007). Standar Kompetensi dan Kopetensi Dasar Tingkat SD/MI. Jakarta : Departemen Pendidikan Nasional.

Costa, A.L. (1988). Developing Mind. Virginia:ASCD

Departemen Pendidikan Nasional. (2006). Kurikulum 2006. Jakarta: Media Makmur Maju Mandiri.

Haryanto. (2006). Sains untuk Sekolah Dasar Kelas IV. Jakarta: Erlangga.

Karli dan Yuliariatiningsih . (2004). Implementasi Kurikulum Berbasis Kompetensi. Bandung: Bina Media Informasi.

Komarul, Umam. (2010). Penggunaan Model STM untuk Meningkatkan Hasil Belajar Siswa pada Konsep SDA. Skripsi FIP UPI Bandung: Tidak diterbitkan. 
Kusniati, Rina. (2010). Meningkatkan Keterampilan Berpikir Rasional Siswa melalui Pendekatan Tematik di Kelas III SD. Skripsi FIP UPI Bandung: Tidak diterbitkan.

Moleong. (2007). Metodologi Penelitian Kualitatif. Bandung: Remaja Rosda Karya.

Poedjiadi, Anna. (2005). Sains Teknologi Masyarakat. Bandung: Remaja Rosda Karya.

Raths, E.L. et al. (1986). Teaching for Thinking. New York and London. Teachers College: Columbia University.

Rostiawaty, S dan Aris M. (2008). Senang Belajar Ilmu Pengetahuan Alam untuk Kelas IV SD. Jakarta: Pusat Pembukuan Depdiknas.

Sagala, Syaiful. (2008). Konsep dan Makna Pembelajaran. Bandung: Alfabeta.

Sanjaya, Wina. (2006). Strategi Pembelajaran Berorientasi Standar Proses Pendidikan. Bandung: Persada Media Grup.

Sardiman. (2010). Interaksi dan Motivasi Belajar Mengajar. Jakarta: Rajagrafindo Persada.

Sudjana (2009). Penilaian Hasil Belajar Proses Belajar Mengajar. Bandung: Remaja Rosda Karya.

Sugiyono. (2010). Metode Penelitian Kualitatif Kuantitatif dan $R \& D$. Bandung: Alfabeta.

Sukirman dan Kasmad. (2006). Pembelajaran Mikro. Bandung: UPI Press

Sumantri dan Permana. (1999). Strategi Belajar Mengajar. Jakarta: Departemen Pendidikan dan Kebudayaan Direktorat jendral Pendidikan Tinggi Proyek Pendidikan Guru Sekolah Dasar.

Sumantri dan Syaodih. (2007). Perkembangan Peserta Didik. Jakarta: Universitas Terbuka.

Suryati, Atty.(2009). Implementasi Pendekatan Kontekstual untuk Meningkatkan Kemampuan Kreativitas Siswa. [Online]. Tersedia: http//digilib.upi.edu/union/ index.php/ record/ view/6936). [13 Maret 2011].

Susilana. (2006). Kurikulum dan Pembelajaran. Bandung: TIM Pengembang MKDP Kurikulum dan Pembelajaran.

Sutardi dan Sudirjo. (2007). Pembaharuan dalam PBM di SD. Bandung: UPI Press.

TN.(2010).Karakteristik Pembelajaran IPA SD. [Online]. Tersedia: http://www.scrbd.com/doc/17087 298/Karakteristik-PembelajaranIPA-SD. [22 Januari 2011].

TN.(2010). Pedoman Penulisan Karya IImiah. Bandung: Universitas Pendidikan Indonesia.

TN. (2010). Undang-undang RI Nomor 20 Tahun 2003 Tentang Sistem Pendidikan Nasional. Bandung: Citra Umbara.

Wardhani. (2007). Penelitian Tindakan Kelas. Jakarta:

Universitas Terbuka.

Windayana, et. al. (2006). Konsep Dasar Matematika. Bandung: Tidak diterbitkan

Yager. (1996). Science Technology Society. New York: State University of New York Press. 
Yuliariatiningsih dan Irianto. (2009).

Pendidikan IPA di Sekolah

Dasar. $\quad$ Bandung: Tidak

diterbitkan.

Yuliariatiningsih, MS. (2000).

Pengembangan Model

Pembelajaran Makhluk Hidup

dan Tumbuhan untuk

Meningkatkan Keterampilan

Berpikir Rasional Siswa SD

Kelas III. Tesis Magister UPI

Bandung: Tidak diterbitkan

Yusuf, Syamsu LN. (2008). Psikologi

Perkembangan Anak dan

Remaja. Bandung: Rosda Karya. 